\title{
The extent to which participants in the indonesian legislative elections obey the rules
}

\author{
Eko Suyono ${ }^{1 *}$, Oman Rusmana ${ }^{1}$, and Agung Praptapa ${ }^{1}$ \\ ${ }^{1}$ Faculty of Economics and Business, Jenderal Soedirman University, Indonesia
}

\begin{abstract}
This study aims to evaluate the extent to which the compliance of legislative candidates as participants of the 2019 Indonesian general election is related to the rules for reporting campaign funds. To achieve this objective, this study uses election rules indicators that relate to the rules of campaign finance reporting with reference to 21 indicators according to Law No. 7 of 2017 concerning General Elections in the Republic of Indonesia along with all derivative rules. Based on the rules that apply in Indonesia, general election participants who do not comply with the rules for reporting campaign funds can be canceled from the process of election as legislative members. In other words, the results of the compliance audit which concludes that a legislative candidate does not comply with the rules for the reporting of campaign funds could be canceled as a legislative member. This study uses the "X" Political Party legislative members from South Kalimantan Province, including legislative candidates for the DPR-RI, Provincial DPRD, and district/city DPRD. The total number of legislative candidates from Party $\mathrm{X}$ is 11 for the DPR-RI from 2 electoral areas, 55 for the Provincial DPRD from 7 electoral areas, and 296 for district/city DPRDs from an average of 5 electoral areas for each district/city. By setting a sample of $20 \%$ of the population, this study ended-up with 74 legislative candidates as the sample., i.e, 3 DPR RI legislative candidates, 11 legislative candidates for the provincial DPRD, and 60 legislative candidates for district/city DPRD. Descriptive analysis method is used to answer the problems in this study. Evaluation of compliance with the reporting of campaign funds is carried out by using compliance audit procedures through review of existing supporting documents and interviews with legislative candidates who are selected as the sample as confirmation procedure. The review of documents is carried out carefully and thoroughly to evaluate whether the legislative candidates from political parties follow the rules in the mechanism of reporting the campaign funds for the period February 20, 2018, until April 25, 2019. After the entire evaluation process conducted in May 2019 has been completed, this study concluded that in general, the legislative candidates adhere to the rules of campaign funds reporting in accordance with applicable laws and regulations. This study does not find any material deviations from applicable laws and regulations.
\end{abstract}

* Corresponding author: ekyo75@unsoed.ac.id 


\section{Introduction}

The general election held in Indonesia on April 17, 2019 is the first simultaneous general elections which simultaneously elect the president and his representatives, legislative members and regional representative councils. This study focuses on the legislative general election where of the 27 parties that register, there are only 16 parties that fulfill the national factual administrative and verification requirements and 4 local parties for the Nangroe Aceh Darussalam Province special area. Verification to determine the requirements for parties that can qualify to participate in the general election includes the existence of the main political party officials at the central level, women's representation of at least $30 \%$, and office domicile at the head office level. Then, at the provincial level, there are additional conditions, namely fulfilling membership in $75 \%$ of districts/cities in 34 provinces. Moreover, the last requirement is the status of the distribution of administrators of at least $50 \%$ of districts in $75 \%$ of districts/cities in 34 provinces.

The political parties participating in the 2019 Legislative Election are as follows: (1) National Awakening Party (Partai Kebangkitan Bangsa/PKB), (2) Greater Indonesia Movement Party (Gerakan Indonesia Raya/GERINDRA), (3) Indonesian Democratic Party of Struggle (Partai Demokrasi Indonesia Perjuangan/PDIP), (4) Golongan Karya Party (GOLKAR), (5) National Democratic Party (NASDEM), (6) Indonesian Change Movement Party (GARUDA), (7) Working Party (BERKARYA), (8) Prosperous Justice Party (Partai Keadilan Sejahtera/PKS), (9) Indonesian Unity Party (PERINDO), (10) United Development Party (Partai Persatuan Pembangunan/PPP), (11) Indonesian Solidarity Party (Partai Solidaritas Indonesia/PSI), (12) National Mandate Party (Partai Amanat nasional/PAN), (13) People's Conscience Party (HANURA), (14) Democratic Party (DEMOKRAT), (15) Aceh Party (PA), (16) Sira Party (SIRA)), (17) Aceh Regional Party (PD Aceh), (18) Nagroe Aceh Party (PNA), (19) Bulan Bintang Party (PBB), and (20) Indonesian Justice and Unity Party (PKPI). Furthermore, the 2019 legislative election which was held on Wednesday (04/17/2019) was to fill 575 seats in the Republic of Indonesia Parliament for the 2019-2024 term. The number increased by 15 seats compared to the previous period in 2014 which only fought for 560 seats (KPU, 2019). In addition, this legislative election was also held simultaneously to fight for seats in the Regional Representatives Council (DPRD) in 34 provinces, 416 regencies and 98 cities in Indonesia.

One of the main issues in the legislative election is the compliance of the election participants with the applicable rules, especially those relating to campaign funds reporting, namely Law No. 7 of 2017 concerning General Elections along with all explanatory rules. Itsis because campaign funds reporting according to the applicable rules is very important to be obeyed by the legislative general election participants to ensure the fulfillment of the principle of free and confidential direct elections according to the mandate of the 1945 Constitution. In order to ensure compliance with such regulations, a compliance audit is required to evaluate how obedient the legislative election participants adhere to the campaign finance reporting rules so that a clean and transparent general election is held without matters that violate the rules.

On the basis of the explanation above, the purpose of this study is to evaluate the level of compliance of legislative election participants in terms of campaign funds reporting in accordance with laws and regulations that apply to the Indonesian Parliament, Provincial DPRD, and Regency/City DPRD in Indonesia.

\section{Literature review and related regulations}

Compliance audit is a work process that determines whether the auditee has followed certain procedures, standards, and rules set by the competent authority (Othman et al., 
2013; Slobodianyk et al., 2018). So the auditor is tasked with ensuring that the work process carried out is in accordance with certain procedures, standards, and rules. In the other side, compliance audit has a purpose to to evaluate the internal performance of the organization and its goal achieving (Gomes, 2001)

The application of compliance audit to the public sector is in line with the new public management (NPM) theory where the theory emerged in the $1980 \mathrm{~s}$

encourage various uses of approaches in the public sector, especially in the field accounting and auditing (Hood, 1995; Reichborn-Kjennerud, 2013). NPM is generally seen as an approach in public administration that applies the knowledge and experience gained in the world of management and other disciplines to improve efficiency, effectiveness of public service performance in modern bureaucracies.

Mintzberg (1980), while describing various types of structural organizations, notes that many public institutions have a simple and healthy organizational structure that he classifies as Machine Bureaucracy. Organizations that have such structures are characterized by hierarchies and simple processes and operations, which repeat themselves, have a standard and predictable form. Therefore, external controls inside such organizations are associated with determining compliance with regulations, standards and procedures. That is why the Machine Bureaucracy is associated with external compliance audit (Mintzberg, 1980). However, more complex organizational structures require different approaches in the field of control to assess not only compliance with regulated standards but also to determine suitability, effectiveness and efficiency.

The compliance audit for the reporting of campaign funds for 2019 legislative elections in Indonesia is based on: (1) Law No. 7 of 2017 concerning General Elections (2) PKPU No. 7 of 2017 concerning Stages, Programs, and Schedule for the Implementation of General Elections in 2019 (3) PKPU No. 5 of 2018 Amendment to PKPU No. 7 of 2017 concerning Stages, Programs, and Schedule for the Implementation of General Elections in 2019 (4) PKPU No. 32 of 2018 Second Amendment to PKPU No. 7 of 2017 concerning Stages, Programs, and Schedule for the Implementation of General Elections in 2019 (5) PKPU No. 24 of 2018 concerning General Election Campaign Funds (6) PKPU No. 29 of 2018 Amendment to PKPU No. 24 of 2018 concerning General Election Campaign Funds (7) PKPU No. 34 of 2018 Second Amendment to PKPU No. 24 of 2018 concerning General Election Campaign Funds (8) SK No. 1126/PL/01.6-Kpt/03/KPU/IX/2018 concerning Campaign Fund Reporting Technical Guidelines (9) SK No. 1781/PL.01.6$\mathrm{Kpt} / 03 / \mathrm{KPU} / \mathrm{XI} / 2018$ concerning Audit Implementation Guidelines on General Election Campaign Fund Reports.

Based on the provisions of General Election Commission (Komisi Pemilihan Umum, hereafter KPU) Regulation Number 24 Year 2018 Article 36, the reporting of political party campaign fund consists of: (1) Campaign Funds Preliminary Report (Laporan Awal Dana Kampanye/LADK) is bookkeeping that contains information on Campaign Fund Special Accounts (Rekening Khusus Dana Kampanye/RKDK), source of initial balance or opening balance, details of income and expenditure calculations obtained before RKDK opening, and receipt of donations sourced from Political Parties or Joint Party Prospective DPD Members or other parties (2) The Report on Receipt of Campaign Fund Donations (Laporan Penerimaan Sumbangan Dana Kampanye/LPSDK) is a bookkeeping containing all receipts received by Election Participants after LADK is submitted to the KPU; and (3) The Campaign Fund Receipt and Expenditure Report (Laporan Penerimaan dan Pengeluaran Dana Kampanye/LPPDK) is a bookkeeping that contains all of the Campaign Funds' receipts and expenses.

The criteria used in this evaluation are in accordance with the provisions stipulated in KPU Regulation Number 24 of 2018 concerning the General Election Funds as amended several times, the latest by the General Election Commission Regulation No. 34 of 2018 
concerning General Election Campaign Funds. These criteria are also used as references and applied by Political Parties in the preparation of campaign fund reports. The criteria that must be obeyed by political parties in compiling campaign fund reports are:

(1) The political parties participating in the election open a Special Campaign Fund Account (Rekening Khusus Dana Kampanye/RKDK) on behalf of the political parties which are separate from the personal accounts of political parties at the public bank and are opened jointly by representatives of 2 (two) political party managers according to their level.

(2) The political parties participating in the election open the RKDK not exceeding the opening provisions of the RKDK which is no later than 1 (one) day before the start of the campaign period.

(3) The political parties participating in the election manage the RKDK by appointing RKDK manager who is specifically tasked to manage the RKDK, which is accompanied by a statement from the political parties.

(4) The political parties participating in the election comply with the bookkeeping period of the Initial Campaign Fund Report (LADK), which is from the opening of the RKDK and closes 1 (one) day before the campaign period.

(5) The political parties participating in the election compile LADK which contains information as follows: RKDK; initial balance or opening balance; source of acquisition of initial balance or bookkeeping balance; amount of details of calculation of receipts and expenditures that have been made before submission of LADK, if the initial balance is the remainder of the receipt of funds with campaign allotment obtained before the period of accounting for LADK; acceptance of contributions originating from political parties and other parties; balance per closing of LADK bookkeeping; and taxpayer identification number.

(6) The political parties participating in the election comply with the submission of LADK not exceeding the stipulated time, namely 1 (one) day after the closing period of LADK no later than 18.00 local time to the KPU, which is completed with: Form the LADK1-PARPOL Model or the LADK1.HP-PARPOL Model form; Form the LADK2-PARPOL Model or the LADK2.HP-PARPOL Model form; Form the LADK3-PARPOL Model or the LADK3.HP-PARPOL Model form; Form the LADK4-PARPOL Model or the LADK4.HP-PARPOL Model form; Form the LADK5-PARPOL Model or the LADK5.HP-PARPOL Model form; Form the Model LADK6-PARPOL or form Model LADK6.HP-PARPOL; and Form the LADK7PARPOL Model or the LADK7.HP-PARPOL Model form;

(7) The political parties participating in the election comply with the bookkeeping period of the Report on the Receipt of Campaign Fund Donations (LPSDK) which starts from 1 (one) day after the closing period of LADK and closes 1 (one) day before the report on receipt of donations is submitted to the KPU.

(8) The political parties participating in the election compile the LPSDK which included the full record for the receipt of Campaign Fund contributions received after the making of LADK.

(9) The political parties participating in the election comply with the submission of the LPSDK not exceeding the time set in accordance with the schedule as stipulated in the KPU Regulation concerning Stages, Programs and Schedules submitted to the KPU no later than 18.00 local time, which is completed with: Form of LPSDK1-Political Party Model; Form of LPSDK2-Political Party Model; Form of LPSDK3-Political Party Model; Form of LPSDK4-Political Party Model

(10) The political parties participating in the election comply with the bookkeeping period of Campaign Funds Receipts and Expenditures Reports (LPPDK) starting 3 (three) 
days after the Political Parties are designated as Participants in the Election and are closed 8 (eight) days after the voting day.

(11) The political parties participating in the election prepare LPPDK which includes the bookkeeping of all receipts of Campaign Funds received and all expenses of Campaign Funds in the form of money, goods and/or services that are converted to monetary value, including debt and purchase discounts for goods or services that exceed the fairness of transactions buying and selling in general is accompanied by proof of expenditure that can be accounted for.

(12) The political parties participating in the election submit Campaign Fund Reports no later than 15 (fifteen) days after voting no later than 18.00 local time to KPU, accompanied by LADK and LPSDK and completed with: Form Model LPPDK1PARPOL; Form Model LPPDK2-PARPOL; Form Model LPPDK3-PARPOL; Form Model LPPDK4-PARPOL; Form Model LPPDK5-PARPOL; Form Model LPPDK6PARPOL; Form Model LPPDK7-PARPOL; Statement of Outside Individual Donors; Statement of Outside Group Donors; Statement of Donors from non-government business entity; Copy of debt (if any); Proof of receipt and expenditure transactions

(13) The political parties participating in the election are responsible that all candidates for $\mathrm{DPR} / \mathrm{DPRD}$ members report and attach the reports on recording the receipt and expenditure of Campaign Funds for candidates for DPR/DPRD members.

(14) The political parties participating in the election record and report on all donations (including money, goods, and/or services that are converted to monetary unit, including debt and discounts on purchases of goods or services that exceed the fairness of general buying and selling transactions) that are accepted into the List of Recipients

(15) The political parties participating in the election record and report on all donations (including money, goods, and/or services that are converted to monetary unit, including debt and discounts on purchases of goods or services that exceed the fairness of general buying and selling transactions) reported in LADK, LPSDK, and LPPDK does not exceed the amount below: IDR 2,500,000,000 for donations by outside individual parties; and IDR 25,000,000,000 for donations of groups and/or non-government business entities.

(16) The political parties participating in the election book and place all donations in the form of money received into the RKDK before being used for campaign activities.

(17) The political parties participating in the election do not use funds from prohibited donations, if accepting donations is prohibited then they should comply with the following provisions: Not using the donation; Report the prohibited donations; and Depositing the prohibited contribution to the country no later than 14 days after the campaign period ends and submitting the KPU's report evidence.

(18) The political parties participating in the election record all Campaign Fund expenditure transactions to the List of Campaign Fund Expenditure Activities.

(19) The political parties participating in the election use fair market prices to assess goods and services in the Campaign Fund receipt and expenditure activities.

(20) The political parties participating in the election do not use Campaign Funds for prohibited provisions, such as financing witnesses in voting and counting.

(21) The political parties participating in the election finance all expenses of the Campaign using funds placed in the RKDK.

\section{Research methodology}

This study uses Political Party " $X$ " with electoral area of South Kalimantan Province which includes Barito Kuala, Tapin, Hulu Sungai Selatan, Hulu Sungai Tengah, Hulu Sungai 
Utara, Balangan, Tabalang, Banjar, Tanah Laut, Tanah Bambu, Kotabaru, Banjarmasin City and Banjarbaru City. The total number of legislative candidates from this political party is 11 for the DPR-RI from 2 electoral areas, 55 for the Provincial DPRD from 7 electoral areas, and 296 for district/city DPRD from an average of 5 electoral areas for each district/city. By setting a sample of $20 \%$ of the population, this study ended-up with 74 legislative candidates as the sample., i.e, 3 DPR RI legislative candidates, 11 legislative candidates for the provincial DPRD, and 60 legislative candidates for district/city DPRD.

Descriptive analysis method is used to answer the problems in this study. Evaluation of compliance with the reporting of campaign funds is carried out by using compliance audit procedures through review of existing supporting documents and interviews with legislative candidates who are selected as the sample in the confirmation procedure. The review of documents is carried out carefully and thoroughly to evaluate whether the legislative candidates from political parties follow the rules in the mechanism of reporting the campaign funds for the period of February 20, 2018, until April 25, 2019. This study was done during May 2019.

\section{Findings and Discussion}

This study implements procedures and obtains relevant and limited evidence on information contained in the Campaign Fund Report submitted to us by the "X" Political Party. In the implementation of insurance engagement, there are limitations inherent, for example, sampling tests conducted allow failure to detect non-compliance and fraud that occurs. There are limitations to the nature, moment, scope, variety, and characteristics inherent in the source of funds as the origin of the Campaign Fund, so there is a possibility that the Campaign Fund is not covered in full in the Campaign Fund report.

Our examination is also limited to documents and/or information submitted and/or provided by the Party concerned so that this study does not carry out checks on matters not disclosed in the report. We do not provide a legal determination of the compliance of Political Parties with the relevant laws and regulations in the Campaign Fund Report.

Moreover, Political Parties are responsible for the preparation of Campaign Fund Reports in accordance with applicable laws and regulations. The responsibility also includes the application of valuation methods, assumptions and estimates used in the report, as well as the design of the implementation, maintenance of systems and processes that are relevant for the preparation of the Report.

Political parties are also responsible for compliance with legislative regulations related to campaign funds, as stated in the Assertion of Political Party Campaign Fund reports as contained in the Attachment to KPU Regulation Number 5 of 2017 on the LPPDK Model 1.

This study concludes with sufficient confidence in the Campaign Fund Report based on the procedures performed and the evidence obtained. We plan and carry out our work to get all the evidence and information needed to determine our conclusions. In carrying out the Engagement with sufficient confidence, we carried out a series of procedures and evaluated sufficient and appropriate evidence including the acquisition of an understanding of the Reporting of Campaign Funds. The nature, timing and scope of the procedures we carry out are also based on professional considerations including the level of materiality and risk assessment. The overview of the procedures that we perform include:

(1) Conducting interviews with Political Parties and/or those who compile the "X" Party campaign finance report.

(2) Conduct inspections of information and/or supporting documents used in preparing campaign fund reports to assess compliance with statutory provisions.

(3) Confirm the receipt of campaign fund contributions from individual donors, business entities, associations and/or political parties. 
(4) Perform recalculation to ensure mathematical accuracy.

(5) Conduct an examination of the completeness and suitability of the report against the coverage period and the deadline for submission of reports.

(6) Conduct checks and tests on recording the receipt of campaign funds against the suitability of the periodic report.

(7) Check the suitability of RKDK ownership of Political Parties against ownership of campaign funds newspaper accounts in Commercial Banks;

(8) Check the suitability of contributors and test the maximum limit of contributions from each type of contributor received by the Political Party "X";

(9) Checking and testing expenses from campaign activities against conformity to Campaign Fund expenditure limits according to regulations;

(10) Check and test, the timeliness of reporting of LADK, LPSDK and donations that are prohibited to the South Kalimantan KPU, as well as verify the list of donations that are prohibited with existing evidence.

(11) Checking the suitability of the report period of receipts and expenditures of Political Parties and conducting tests on receipts and expenditures.

(12) Checking the suitability of the RKDK opening at the Bank that has been determined and the ownership of the RKDK in accordance with the provisions.

(13) Check the suitability of LADK coverage and the completeness of the information included in LADK.

(14) Check the suitability of the LPSDK coverage and the completeness of the information included in the LPSDK.

Our examination reveals that in general the " $\mathrm{X}$ " political party and its legislative candidates adhere to the provisions of legislation and report campaign funds in terms of managing the receipt and expenditure of campaign funds in the form of money originating from donations from Legislative Candidates through the RKDK.

\section{Conclusion}

This study aims to evaluate the level of compliance of legislative election participants in terms of campaign funds reporting in accordance with laws and regulations in Indonesia. By using 74 legislative candidates form Political Party " $\mathrm{X}$ " in the South Kalimantan electoral area, this study concludes that except for some points which are not material, the Political Party in the Campaign Fund Report above, in all material matters, are in accordance with the applicable criteria as stipulated in KPU Regulation Number 24 Year 2018 concerning the General Election Fund as several times last amended by General Election Commission Regulation No. 34 of 2018 concerning General Election Campaign Funds.

\section{References}

1. M. B. Gomes, Performance Audit Argument: A Public Management Policy Analysis about Supreme Audit Institutions Role (Caracas, 2001)

2. C. Hood, Accounting, Organ. Soc. 20, 93 (1995)

3. H. Mintzberg, Manage. Sci. 26, 322 (1980)

4. R. Othman and N. Mahzan, NZICA. 31 (2013)

5. K. Reichborn-Kjennerud, Does Performance Auditing Matter? The Government Administration's Response to the Performance Auditing of the Norwegian Office of the Auditor General, University of Bergen, 2013 
6. Y. Slobodianyk, S. Shymon, and V. Adam, Balt. J. Econ. Stud. 4, 320 (2019)

7. Law No. 7 of 2017 concerning General Elections

8. PKPU No. 7 of 2017 concerning Stages, Programs and Schedule for the Implementation of General Elections in 2019

9. PKPU No. 5 of 2018 Amendment to PKPU No. 7 of 2017 concerning Stages, Programs and Schedule for the Implementation of General Elections in 2019

10. PKPU No. 32 of 2018 Second Amendment to PKPU No. 7 of 2017 concerning Stages, Programs and Schedule for the Implementation of General Elections in 2019

11. PKPU No. 24 of 2018 concerning General Election Campaign Funds

12. PKPU No. 29 of 2018 Amendment to PKPU No. 24 of 2018 concerning General Election Campaign Funds

13. PKPU No. 34 of 2018 Second Amendment to PKPU No. 24 of 2018 concerning General Election Campaign Funds

14. SK No. 1126/PL/01.6-Kpt/03/KPU/IX/2018 concerning Campaign Fund Reporting Technical Guidelines

15. SK No. 1781/PL.01.6-Kpt/03/KPU/XI/2018 concerning Audit Implementation Guidelines on General Election Campaign Fund Reports. 